material were always made at a distance from the tumour. The amount of necrosin administered in the fluid state varied from an equivalent dose of $0.2 \mu \mathrm{gm}$. of necrosin to $1,748 \mu \mathrm{gm}$. of lyophilized necrosin. After one or several injections, the material induced hæmorrhagic or other forms of necrosis, such as a mucoid-like yellowish fluid, or rarely a caseous-like central necrosis, in the tumour. Hæmorrhagic necrosis was also found to occur in some of the metastatic foci of the lung. A certain amount of necrosis in these areas appeared as early as one hour after the administration of necrosin. This toxic substance concomitantly causes hepatic injury in the form of vacuolation of the cytoplasm of the liver cells. Sometimes one encounters various forms of leucocytic infiltration in the liver. Whether or not the hepatic injury is the cause of the death of the animal is not yet clear. At times, injury to the kidney is also seen in the form of foci of leucocytes. This and other factors are at present under investigation, for to date there is no evidence that the span of life is prolonged with necrosin treatment. Nevertheless, the effect is specific and does not occur with other protein fractions, such as the euglobulin of normal blood serum or with papain. Further work is being conducted with different strains of mice; methods are also being devised to counteract the toxic effect of necrosin on the liver.

VALY MENKIN

Agnes Barr Chase Foundation for Cancer Research, Temple University School of Medicine, Philadelphia, Pennsylvania.

$$
\text { Sept. } 8 .
$$

'Menkin, Science, 105, 538 (1947); Lancet, i, 660 (May 17, 1947).

'Menkin, Arch. Path., 36, 269 (1943): 39, 28 (1945).

${ }^{3}$ Ludford, R. J., Proc. Roy. Soc., B, 104, 493 (1929).

${ }^{4}$ Duran-Reynals, F., Amer. J. Cancer. 35. 98 (1939).

\section{Para-Aminobenzoic Acid in Human Leukaemias}

BICHEL $^{1}$, and later Zarafonetis and co-workers ${ }^{2}$, recorded interesting data concerning the effect of para-aminobenzoic acid in leukæmias.

In an attempt to confirm Bichel's findings, we investigated the effect of a single intravenous injection of $p$-aminobenzoic acid on patients with leukæmias, and on controls; we administered the sodium salt in 3-5 per cent solution. The intravenous infusions were given for 10-21 minutes. In each case the total amount was $5 \mathrm{gm}$. The $p$-aminobenzoic acid serum levels (maximum) ranged from 18 to $31 \mathrm{mgm}$. per cent.

We made nine trials in seven patients with leukæmias and six trials in six persons not suffering from this group of diseases. The patients tested could be grouped as follows according to clinical condition : three chronic myelocytic leukæmic myeloses, one sub. chronic promyelocytic-myelocytic leukæmic myelosis, one chronic subleukæmic lymphoid leukosis, one chronic aleukæmic lymphoid leukosis, and one acute paraleukoblastic form. The group free from leukæmia included one healthy individual, one with Hodgkin's disease, one with Vaquez-Osler disease, one with cirrhosis hepatis, one with Besnier-Boeck-Schaumann disease, and one case of rheumatic fever.

We found that all four patients with myelocytic leukæmia developed a fever response, with chill and shivering, which occurred between one and four hours after the injection had been given. The fever might exceed $39^{\circ} \mathrm{C} .\left(102^{\circ} \mathrm{F}.\right)$, and showed no close relationship to the $p$-aminobenzoic acid blood-level or to the speed of the infusion. The two patients with lymphoid leukæmias and the case of acute paraleukoblastic form did not show this reaction; nor did the nonleukæmic controls.

The total and differential leucocyte counts, and the cells of the spleen (the latter were examined in only two cases), did not show constant significant deviations. It was remarkable that in our leukæmic patients the renal elimination of $p$-aminobenzoic acid occurred in the same manner as we have described for healthy individuals.

Our evidence to date indicates that the phenomenon here noted cannot be obtained if the leucocyteproducing system is under the influence of a com. pletely developed urethane effect ${ }^{3}$.

We suggest a humoral basis for the shivering and fever, and conclude that it may be caused by some substance liberated from the leukæmic leucocytes as a result of the administration of $p$-aminobenzoic acid. To confirm this view, experiments are in progress with whole blood, with serum, and with leucocytes, etc., inoculated into guinea pigs.

We hope to publish the results of these tests, and also of the investigation reported above, in detail later elsewhere.

\section{Clinic for Internal Medicine, University of Szeged, Hungary. Aug. 2. \\ * Working with a grant from the Lady Tata Memorial Trust. ${ }^{1}$ Bichel, Nature, 161, 353 (1948). \\ 2 Zarafonetis, et al., Blood, 3, 780 (1948). \\ 3 Kelemen, Benkö and Tényi (unpublished). \\ E. KELEMEN* \\ M. TÉNYI \\ Failure of Transmission of Motor and Sensory Nerve Impulses after Nerve Section}

HITHERTo the time at which failure of transmission of nerve impulses occurs following section of the nerve trunk has been determined in mixed nerves only. In the popliteal and sciatic nerve of the cat it was found to occur after about three and four days respectively ${ }^{1,2}$. Erlanger and Schoepfle ${ }^{3}$ found degeneration in the phrenic nerve to be complete after about four days.

It is possible that failure of impulse transmission after nerve section sets in at different times in different groups of nerve fibres. Indeed, Moenkeberg and Bethe ${ }^{4}$ had shown histologically that degeneration proceeds more quickly in sensory than in motor nerve fibres, and von Muralt ${ }^{5}$ as well as Rosenblueth and Dempsey ${ }^{6}$ consider that the thick nerve fibres with a rapid conduction-rate degenerate earlier than the thin, slowly conducting ones. Rosenblueth and Dempsey found that in a few nerves the $A$ spike had already considerably decreased at a time at which the $C$ spike was still normal. They supported their conclusion also by the fact that the rate of conduction increased in the degenerating nerves when the stimulating electrode was moved peripherally towards the recording electrode, suggesting that degeneration followed a centrifugal course. However, Erlanger and Schoepfle showed that failure of nerve conduction does not proceed centrifugally, but that 